\title{
Greater Port Harcourt City Urbanization Project and Its Socio-economic Effect on Affected Farming Communities in Rivers State
}

\author{
Franklin Nlerum $^{1, *} \&$ Ezebunwo Wechie ${ }^{1}$ \\ ${ }^{1}$ Department of Agricultural Extension and Rural Development, Rivers State University, \\ PMB 5080, Port Harcourt, Nigeria \\ *Corresponding author: Department of Agricultural Extension and Rural Development, \\ Rivers State University, PMB 5080, Port Harcourt, Nigeria. E-mail: frankezi@yahoo.com
}

Received: December 28, 2017 Accepted: January 6, 2018 Published: January 26, 2018

doi:10.5296/jsr.v9i1.12552 URL: https://doi.org/10.5296/jsr.v9i1.12552

\begin{abstract}
The study was on Greater Port Harcourt City urbanization project and its socio-economic effect on affected farming communities in Rivers State, Nigeria. Random sampling technique was used in selecting 100 farmers in farming communities affected by the project. Data were elicited with the interview schedule and analyzed with percentage and mean. The t-test was used in the test of hypothesis. Results indicated that the major social effects of the project on farming communities were conversion of farm land into building and road projects $(85.00 \%)$ and reduced farm labor $(70.00 \%)$. Those of economic effects were decreased agricultural output $(70.00 \%)$ and high cost of land lease for agricultural production $(64.00 \%)$. There was a significant difference between social and economic effects of the urban expansion project on farming communities. The study recommends the provision of farm reserved areas, enhanced environmental friendly activities, enhanced farm input supply, and provision of credit to reduce the cost of land lease for agriculture.
\end{abstract}

Keywords: Greater Port Harcourt; Urbanization project; Farming communities; Social-economic effects 


\section{Introduction.}

Greater Port Harcourt City Development Authority (GPHCDA) is a regulatory body established by law with mandate to facilitate the implementation of the Greater Port Harcourt Master Plan and build the new Greater Port Harcourt City (Government of Rivers State of Nigeria, Greater Port Harcourt information booklet, 2009). Rivers State is known as the garden city of the Federal Republic of Nigeria. Upon assumption of office on October 26, 2007, the erstwhile administration of Rivers State, led by the governor, Rt. Hon. Chibuike Romiti Amaechi, spent no time in unveiling its development agenda, part of which was the Greater Port Harcourt City project.

One of the earliest demonstrations of Amaechi's commitment to the Greater Port Harcourt project came with the commissioning of Arcus GIBB, a reputable South African engineering firm, to study the entire landscape surrounding the state capital and produce a master plan for the development of a new Port Harcourt city.

The New City master plan covers Port Harcourt and parts of seven other local government areas, namely Obio/Akpor, Ikwerre, Etche, Oyigbo, Eleme, Okrika and Ogu/Bolo. It occupies a land area of 190,000 hectares (about 1,900 sq. km) with a projected population of two million. So far, GPHCDA's master plan implementation approach has been quite methodical and involves a phased development of the New City beginning with Phase 1 which is divided into $\mathrm{A}, \mathrm{B}, \mathrm{C}$, and D, located in the northern axis of the plan, near the Port Harcourt International Airport.

Vision Statement of the project is to transform the Greater Port Harcourt Area into a world class city, internationally recognized for excellence and the preferred destination for investors and tourists. Its mission statement; is to build a well-planned city, through the implementation and enforcement of policies that will ensure the provision of first rate infrastructure and delivery of quality services to enhance the standard of living and well-being of the people(Government of Rivers State of Nigeria Greater Port Harcourt (GPHCDA) information booklet, 2012).

The area covered is predominantly made up of large number of farm families (community), whose primary occupation is farming and its related activity such as hunting and lumbering. Over $70 \%$ of the population engages in farming to meet the demands of the increasing population of the state.

The process of urbanization is one of the most important drivers of economic, social and physical change in developed countries such as those in Sub-Saharan Africa(Pieterse 2008), Aquilar and Ward (2003) indicate that rapid urban population growth has thus led not only to an increasing demand for urban land particularly housing, but also for various urban uses. In many countries, the increasing demand for land has affected peri-urban areas, where urban expansion has already encroached into agricultural land and small villages. According to Mcgregor, et al. (2006), managing the urban growth in rural-urban fringe is however complex and conflict ridden in developing nations. Transforming agriculture and land conversion in rural-urban fringe eats into agricultural land, thus leading to the reduction in the quantity and 
quality of land for farming. When farming is affected by various factors that make it an unviable enterprise, farmers diversify crop production to off farm jobs. Hardship is encountered by farmers due to distraction and lack of experience in other means of livelihood. Fear for land conversion is the reason most farmers auction their available land for sales before falling victim to urbanization. With declining communal and culturally bound families, strangers infiltrate the system, socialize with the natives and thereby take over the communal heritage of rural farmers. This scenario is detrimental to the children and the unborn that will become ignorant of their traditional values.

According to Orum (2005), urbanization is a process whereby large number of people congregate and settle in an area, eventually developing social institutions such as government and business in order to support themselves. The known causes of urbanization are: industrial revolution, emergence of large manufacturing center, progeny of job opportunities, availability of easy transportation and migration (Saiyangoku, 2011). The positive effects of urbanization are: reduced transport costs, exchange of ideas, distribution of natural resources, opportunities to people on social amenities that are lacking in the countryside, disappearing of social and obnoxious taboos and sanctions, provision of education as a tool to eradicate social evils, industrialization, establishment of new cities, education, legislation, secularization of development, diffusion of urban culture to rural areas, etc. The negative effects of urbanization are: environmental pollution of land, water and air, spread of communicable diseases, overcrowding, unemployment and under-employment, severe shortage of housing and transportation leading to commuting issues.

Urbanization is often considered as having negative effects on agriculture due to loss of agricultural land to urban expansion (Macgranaham, Satterthwaite and Tacoli 2010). Also, the youths who were supposed to be gainfully employed in farms have no option than to join in roaming about the streets, towns and cities in search for white collar jobs. Others engage in petty trading without training, while the females subject themselves to different odd jobs in order to meet up with social demands.

The problem of the study was to know if the GPHC urbanization project has got some effects on the affected farming communities in Rivers State.

The research question therefore of the study were, what are the socio-economic characteristics of the farmers and what are the social and economic effects of GPHC urbanization project on the affected farming communities?

The objectives of the study were to describe the socio-economic characteristics of farmers affected by the project and determine the social and economic effects of the Project on farmers in the study area. The arising hypothesis of the study was, there is no significant difference between social and economic effects of the Project on affected farming communities in Rivers State. 


\section{Research Methodology}

The study area for this study was Rivers State. Rivers State, also known simply as Rivers, is one of the 36 states of Nigeria. According to census data released in 2006, the state has a population of 5,185,400, making it the sixth-most populous state in the country. Its capital, Port Harcourt is large and is economically significant as the center of Nigeria's oil industry. Rivers State is bounded on the South by the Atlantic Ocean, to the North by Imo, Abia and Anambra States, to the East by Akwa Ibom State and to the West by Bayelsa and Delta States. It is home to many indigenous ethnic groups such as the Ikwerre, Ibani, Opobo, Eleme, Okrika, and Kalabari, Etche, Ogba, Ogoni, Engenni and others.

Rivers State, named after the many rivers that border its territory, was part of the Oil Rivers Protectorate from 1885 till 1893, when it became part of the Niger Coast Protectorate. In 1900 the region was merged with the chartered territories of the Royal Niger Company to form the colony of Southern Nigeria. The state was formed in 1967 with the split of the Eastern Region of Nigeria. Until 1996 the state contained the area now known as Bayelsa State. The State is made up of 23 (twenty-three) Local Government Areas (LGA's).

Port Harcourt was established in 1912 as a railway terminus by the colonial authorities. It was characterized by well-planned and maintained infrastructures, well laid out buildings and streets, parks and gardens. It was therefore known as the Garden City. Over the years, Port Harcourt has been stripped off, of its beauty due to the following;

- Rapid increase in population due to influx of people

- Distortion of city plan and poor management

- Uncontrolled and unplanned spatial expansion

- Infrastructure decay.

The population of the study comprised of the eight Local Government Areas affected by the projects in Rivers State. Random sampling method was first used in selecting three out of the eight LGA`s affected by the urbanization project. The selected LGA`s were Eleme, Etche and Ikwerre. Random sampling was also used in selecting three communities in each of the LGA to have a total of nine. The communities were Ebubu, Nchia and Onne for Eleme LGA. Afara, Igbo and Umuechem for Etche LGA. Aluu, Igwuruta-Ali and Omuagwa for Ikwerre LGA respectively. Furthermore, the random sampling technique was employed in selecting 11 farmers from each of the previously selected nine communities apart from Aluu that had 12 farmers. This was how the sample size of 100 farmers used for the study was achieved. Primary data were elicited with copies of the interview schedule which were administered to the farmers by one of the authors. The data collected were analysed using descriptive method of data analyses, such as percentage and mean. Inferential statistics of t-test was used for test of the study hypothesis.

The model for computation of the t-test was: 


$$
t=\frac{\overline{x_{1}}-\overline{x_{2}}}{\sqrt{\frac{S_{P_{1}}^{2}}{n_{1}}+\frac{S_{P_{2}}^{2}}{n_{2}}}}
$$

Where: $\mathrm{t}=$ Test for the two treatment means

$\overline{x_{1}}=$ Mean of social effect

$\overline{x_{2}}=$ Mean of Economic effect

$n_{1}=$ Number of Observations for social effect

$n_{2}=$ Number of observations for economic effect

$S_{1}^{2}=$ Variance for social effect

$S_{2}^{2}=$ Variance for economic effect

$S_{p}^{2}=$ Poole variance for social and economic effect

\section{Results and Discussion}

\subsection{Socio-economic Characteristics of the Respondents}

Table 1 shows that $70 \%$ and $30 \%$ of the respondents were males and females respectively, indicating that there was more male than female farmers in the affected communities. The Mean age of correspondents was 34.60 years. These shows there were younger farmers in the study area. The table also shows that majority $(60 \%)$ of the respondents were married. This connotes that these respondents hard family members who were also affected by the negative effect of the project in the study area.

The mean of education was 7.16 years. The highest level of educational qualification was Secondary school with $65 \%$. 


\section{Macrothink \\ Journal of Sociological Research \\ ISSN 1948-5468 \\ 2018, Vol. 9, No. 1}

Table 1. Socio-economic Characteristics of Respondents

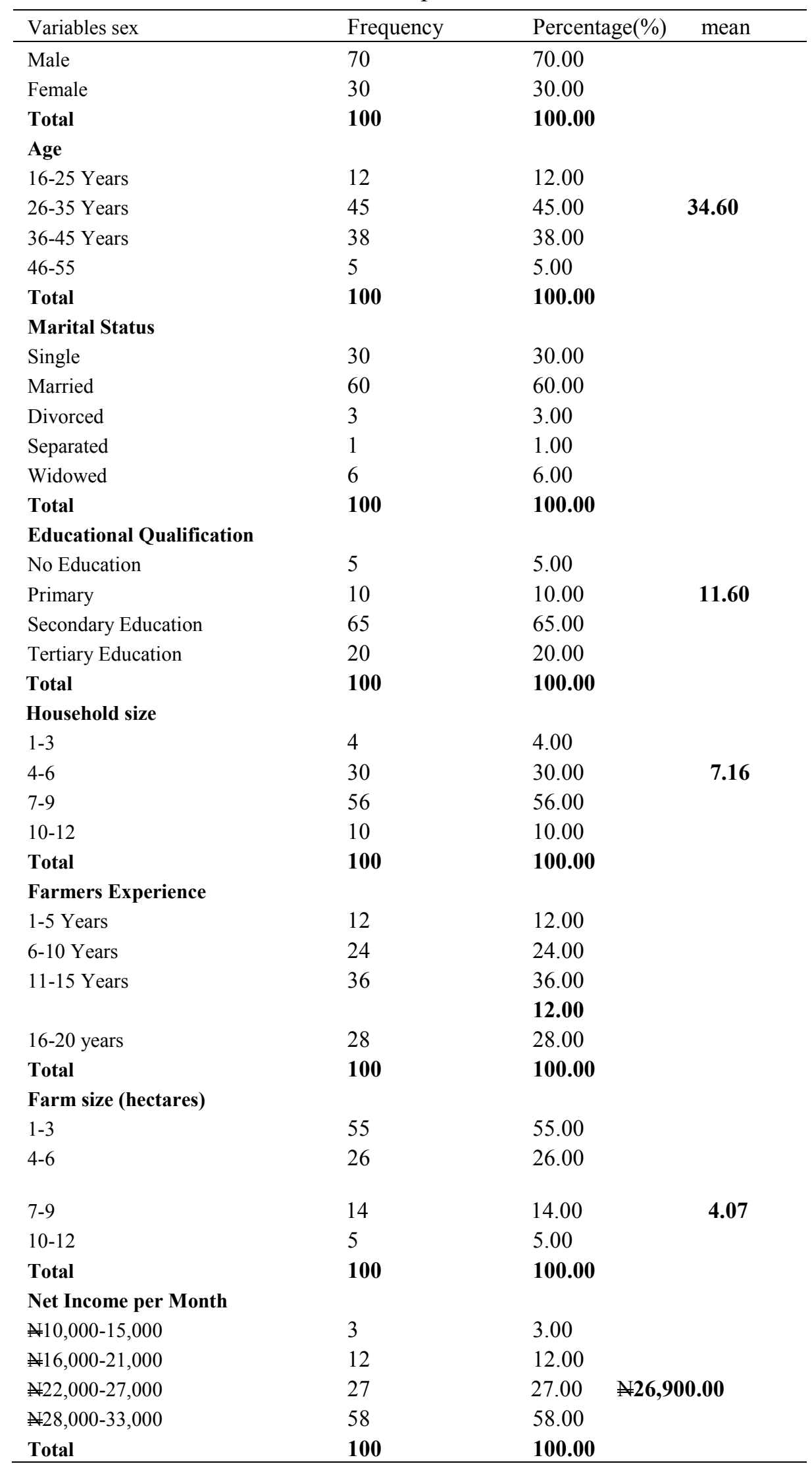

Source. Field Survey 2017. 


\subsection{Social effect of Greater Port Harcourt City (GPHC) on Affected Farming Communities}

The results in Table 2 shows that the conversation of farm lands to building and road projects with $85.00 \%$ was the major social effect of GPHC urbanization project on the farming communities

Table 2. Social Effect of Greater Port Harcourt city Urbanization Project on Farming Communities

\begin{tabular}{lll}
\hline \multicolumn{1}{c}{ Effects } & $\begin{array}{c}\text { Percentage (\%) } \\
\text { (n = 100) }\end{array}$ & Remark \\
\hline Reduced farm labour & 70.00 & Negative \\
Conversion of farm lands to building and road projects & 85.00 & Negative \\
Decreased interest in farming & 55.00 & Negative \\
Over population in farming communities & 60.00 & Negative \\
Environmental pollution of farming communities due to & 65.00 & Negative \\
increased human activities & & \\
Improvement in infrastructure & 76.00 & Positive \\
Percentage total score & 402.00 & \\
Percentage & 67.00 & \\
\hline
\end{tabular}

Source: Field survey, 2017. Multiple response.

This finding agreed with the study of Winfield (1973) which indicated that one effect of urbanization on agriculture production was that land conversion to urban used increased. This social effect portrayed a negative consequence to farming communities which were affected by GPHC urbanization project. This finding meant that the amount of farm land available to each farming household was reduced, while some households were completely displaced by reason of the fact that the amount of farm lands which are now converted to building roads and other urban expansion activities. Further implication of this result is that many of the farmers were displaced from farming which is their natural occupation. This assertion confirmed the result of the study of Jiang et al (2013) which indicated that urban expansion in China was associated with a decline in agricultural land use.

The second major social effect of greater Port Harcourt City Project on the affected farming communities was that it reduced farm labour as shown by $70.00 \%$ of the respondents. Farmers who were displaced by the project migrated to seek for livelihood from non-farm professions. This process reduced the labour which was available for agriculture. Some migrated from rural farm communities to non-farm locations to seek for alternative means of income. Migration results in the neglect of agriculture in agreement with the study of Koko and Abdullahi, (2012).

Improvement in infrastructure with $67.00 \%$ was the third major social effect of Greater Port Harcourt City urbanization project on the affected farming communities. This result portends a positive influence on the study area. This finding agreed with that of Dociu and Dunarintu (2012) which earlier indicated that urbanization led to the development of infrastructure of the areas affected. Rural infrastructure in farming communities which are likely to be 
improved by GPHC project were housing, roads, communication, electricity, potable water, hospital etc.

The Findings in Table 2 has also shown that the overall social affect of the project on farming communities had more negative than positive influence on the farmers. This is because, out of the six social effects that were analysed, as much as five of them showed negative effects as accounted for by the percentage means score of $67.00 \%$ in Table 2 . This finding implies that the project portends a negative social consequence to agriculture in line with the study of Winoto and Schultink (1996). The findings of these researchers indicated that among the rural farmers of West Java in Indonesia, urbanization consequences resulted in the increase of landless farming households, absentee agricultural land ownership, parcelizaiton of farmlands, conversion of agricultural lands to non-agricultural uses, transformed self-employed farmers to non-farmers, increased rural-urban migration and reduced the welfare of rural farmers.

\subsection{Economic Effect of Greater Port Harcourt City Project on Affected Farming Communities}

The results in Table 3 shows that decrease in agricultural output as indicated by $70.00 \%$ of the farmers was the primary economic effect of Greater Port Harcourt city expansion project on the affected farming communities. This result confirmed the result in the study of Iheke and Ukandu (2015) where urbanization led to decrease in agricultural production in Abia State, Nigeria. The result also agreed with the study of Yan et al (2015) in China. This result is expected in this study since the quantity of land to farmers has been reduced due to Port Harcourt City urban expansion and encroachments. The other adduced reason for low productivity in agricultural output among affected farming communities by GPHC Urban expansion project was that the scheme led to change in attitude of farmers to agriculture in preference for non-farm jobs. This reason is in agreement with the assertion of Berry (2006) which showed that urbanization resulted in negative changes in attitudes about farming and status of farmers.

Table 3. Economic Effect of Greater Port Harcourt City Urbanization Project in Farming Communities

\begin{tabular}{lll}
\hline Effects & Percentage \% & Remark \\
\hline High cost of land lease for agricultural production & 64.00 & Negative \\
Increase demand for farm products & 40.00 & Positive \\
Decrease in agricultural output & 70.00 & Negative \\
Destruction of traditional livelihood & 66.00 & Negative \\
High cost of living & 60.00 & Negative \\
Mix-economic opportunities at expense of farming & 40.00 & Negative \\
Increase in rent & 62.00 & Negative \\
Rise in value of land & 68.00 & Positive \\
Percentage total score & 470.00 & \\
Percentage mean score & 58.75 & \\
\hline
\end{tabular}

Source: Field survey, 2017, multiple response. 
High cost of land lease for agriculture production as indicated by $64.00 \%$ of the farmers was the next major economic effect of Greater Port Harcourt city urban expansion project on the affected farming communities. The reason for this was that since much of the farm land have been designated for urban expansion, the remaining land for farming has become expensive to lease by agricultural practitioners. This problem was made worst by the work of Berry ((2006) which is associated with city expansion.

Mix-economic opportunities at the expense of farming with $62.00 \%$ wass the next negative social effect of Port Harcourt City (GPHC) urbanization project to its affected farming communities. It was true that GPHC project provided mix-economic opportunities in the affected rural communities. Be this as it may, the opportunities had negative influence on farmers because their concentration of effort on agriculture as their primary means of livelihood was disrupted by the urban expansion project of GPHC. The result of this loss in concentration of effort in agriculture would show in low agricultural output of the communities at harvest time.

The results in Table 3 has clearly shown that the overall economic effect of the Greater Port Harcourt City urban expansion project on the affected farming communities was more negative than positive. The status of the economic negative effect on farming in the area was $58.75 \%$. This means that the project is having adverse effect on farming activities in the affected rural communities.

Table 4. Summary of t-test Showing Significant Difference between Social and Economic Effect of Port Harcourt City Urbanization on Farming Community

\begin{tabular}{llllll}
\hline Df & Mean & Tcal. & Ttab0.05(10) & Decision & Reason \\
\hline 10 & 62.88 & 1.27 & 2.14 & Accept & $\mathrm{T}_{\text {cal. }}<\mathrm{T}_{\text {tab }}$ \\
\hline
\end{tabular}

Source: Field survey, 2017. Alpha $=0.05$

The results in Table 4 show that there was no significant difference between the status of social and economic effects of the effected farming communities in Rivers State. The reason for this assertion was because the t-calculated (1.27) was less than the t-tabulated (2.14), which resulted in the acceptance of the null hypothesis of the study.

\section{Conclusion and Recommendations}

The study has shown that the overall socio-economic effect of Greater Port Harcourt city urbanization project was mainly negative on affected farming communities of Rivers State. Succinctly, the major social effects of the project were conversion of farm lands to building and road projects, reduced farm labour and environment pollution of farming communities due to increased human activities. The major economic effects of the project were decreased agricultural output, high cost of land lease for agricultural production and mix-economic opportunities in expense to farming. The study recommends the reservation of certain land 
area for farming, reduced human urban pollution activities, enhanced agricultural input support programmes to boast farm output and provision of credit to reduce high cost of agricultural land lease in the area.

\section{References}

Abdullahi, D., \& Koko, I. S. (2012). Effect of migration of farmers to sustainable livelihood in Nigeria. IOSR Journal of Business and Management, 3(3), 10-14. https://doi.org/10.9790/487X-0331014

Aquilar, A., \& Ward, P. (2003). Globalization, regional development and mega city expansion in Latin America: Analyzing Mexico city`s peri-urban hinter land, cities. 20(1). https://doi.org/10.1016/S0264-2751(02)00092-6

Berry, D. (2006). Effects of Urbanization on Agricultural activities. Growth and change, 9(3), 2-3. https://doi.org/10.1111/j.1468-2257.1978.tb01024.x

Dociu, M., \& Dunarintu, A. (2012). The socio-economic impact of urbanization. International Journal of Academic Research in Accounting, Finance and Management Sciences, 2(1), 47-53

Government of Rivers State of Nigeria, (2009) Greater Port Harcourt information booklet. Retrieved on $20^{\text {th }}$ February, 2017 from Website:www.greaterphc.comTel:084-465650

Iheke, O. R., \& Ukandu, I. (2015). Effect of urbanization on agricultural production in Abia State. International Journal of agricultural science, Research and Technology in Extension Education Systems, 5(2), 83-89.

Jiang, L., Deng, X., \& Seto, K. C. (2013). The impact of urban expansion on agricultural land we intensify in China. Land use policy, 35, 33-39. https://doi.org/10.1016/j.landusepol.2013.04.011

McGranahan, G., Satterthwaite, D., \& Tacoli, C. (2010). Urbanization and its implication for food and farming. Journals of philosophical transactions B. United States national library of medicine, national institution of health. Retrieved from www.ncbi.nlm.nih.gov/pmc/articles/pmc2935117/

Mcgregor, D., Simon, D., \& Thompson, D. (2006). The peri-urban interface. Approaches to sustainable natural and human resource use.313. Earth Scan, Sterling, (151), 51-164.

Orum, A. (2005). Urbanization. In G. Ritzer (Ed.), encyclopedia of social theory. (pp. 853-859). Thousand Oaks, CA: SAGE publications, Inc. https://doi.org/10.4135/9781412952552.n318

Pieterse, E. A. (2008). City Futures: Confronting the Crises of Urban Development. London; New York: Cape-town, South Africa Zed books; UCT press. 


\section{Macrothink}

Saiyangoku, (2011). Five effects of urbanization. Retrieved on $20^{\text {th }}$ February, 2017 from https// www.slideshare.net/saiyangoku/5effects-of-urbanization.

Winfield, G.F. (1973). The Impact of Urbanization on Agricultural Processes. The Annuals of the American Academy of Political and Social Science, 405(1), 65-74. https://doi.org/10.1177/000271627340500108

Winoto, J., \& Schultink, G. (1996). Impact of urbanization on Agricultural Sustainability of Rural Life in West Java, Indonesia. Michigan Agricultural Experiment Station, Research Report 545, Michigan State University, pp 1-56.

Yan, T., Wang, J., \& Hung, T. (2015). Urbanization and agricultural water use and regional and national crop production in China. Ecological modeling, 318(2015), 221-235.

\section{Copyright Disclaimer}

Copyright for this article is retained by the author(s), with first publication rights granted to the journal.

This is an open-access article distributed under the terms and conditions of the Creative Commons Attribution license (http://creativecommons.org/licenses/by/3.0/). 